\title{
A Protease Inhibitor of the Serpin Family Is a Major Protein in Carp Perimeningeal Fluid: I. Protein Purification and Characterization
}

\author{
*Chang-Jen Huang, †Chien-Chang Chen, *Hsiu-Jane Chen, \\ $* \dagger$ Fore-Lien Huang, and $\ddagger$ Geen-Dong Chang \\ *Institute of Biological Chemistry, Academia Sinica; and $\dagger$ Department of Zoology and $¥$ Graduate Institute \\ of Biochemical Sciences, National Taiwan University, Taipei, Taiwan
}

\begin{abstract}
Two isoforms of a protease inhibitor of the serpin family (p62) have been purified from bighead carp perimeningeal fluid. Both isoforms migrate with an apparent molecular mass of $62 \mathrm{kDa}$ on reducing and nonreducing sodium dodecyl sulfate-polyacrylamide gels. Both proteins inhibited the activities of bovine trypsin, bovine chymotrypsin, and porcine pancreatic elastase. They also formed complexes with these proteases that were resistant to sodium dodecyl sulfate treatment. p62 exists in the extracts of all tissues examined, including brain, head kidney, kidney, liver, muscle, ovary, pituitary, and spleen It is also present in serum, ovarian fluid, and milt as well as perimeningeal fluid. The protease inhibitor is a glycoprotein, and its carbohydrate moiety could be removed by endoglycosidase F. Because p62 resembles mammalian $\alpha_{1}$-antitrypsin in many aspects, it is likely a fish equivalent of $\alpha_{1}$-antitrypsin. Key Words: Protease inhibitorSerpin-Perimeningeal fluid-Serine protease.

J. Neurochem. 64, 1715-1720 (1995).
\end{abstract}

The CSF bathes the subarachnoid space, ventricles, and cavities inside the brain. Substances in the CSF freely exchange with the extracellular fluid surrounding the neurons and glial cells (Spector and Johanson, 1989; Nilsson et al., 1992). Therefore, maintenance of a stable milieu for the brain is achieved by maintaining a stable composition in the CSF. However, the CSF system in fish is devoid of a subarachnoid space, and the space between the meninx and the skull is filled with perimeningeal fluid (PMF), also known as extradural fluid (Jones, 1979). The PMF has been reported to be a mixture of serum and CSF (MüllerSchmid et al., 1992). PMF has also been reported to have the same protein composition as CSF (Shashoua, 1985).

It is generally believed that most of the proteins present in mammalian CSF are of blood origin because two-dimensional electrophoretic profiles of CSF and serum proteins are similar (Walsh et al., 1984; Wiederkehr et al., 1987). In contrast, ependymins ( $\beta$ and $\tau$ ) represent the most abundant proteins in both CSF and PMF in fish systems, and they are present only in CSF and PMF (Hoffmann, 1992; Müller-Schmid et al., 1992). Protein concentrations in CSF and PMF in fish are more than an order of magnitude higher than the protein concentration in CSF in mammals. Because larger samples can be collected from PMF than from CSF, we decided to study protein components present in bighead carp PMF. In this article, we describe purification of two isoforms of a 62-kDa protease inhibitor that formed complexes with and inhibited the activities of bovine trypsin, bovine chymotrypsin, and porcine pancreatic elastase.

\section{MATERIALS AND METHODS}

\section{Materials}

Bovine $\alpha$-chymotrypsin, porcine pancreas elastase, $N$ tosyl-Gly-Pro-Arg- $p$-nitroanilide, $N$-succinyl-Ala-AlaPro-Phe- $p$-nitroanilide, $N$-succinyl-Ala-Ala-Pro-Leu- $p$-nitroanilide, bovine serum albumin, Freund's adjuvant, and horseradish peroxidase-conjugated anti-guinea pig IgG (A5545) were purchased from Sigma Chemical Co. (St. Louis, MO, U.S.A.). Bovine $N$-tosyl-L-phenylalanine chloromethyl ketone-treated trypsin was from Worthington (Freehold, NJ, U.S.A.). The TSK-phenyl 5PW column for HPLC was from E. Merck (Darmstadt, Germany). Endoglycosidase $\mathrm{F}$ and bovine serum albumin-free $O$-glycosidase were from Boehringer Mannheim (Mannheim, Germany). Acrylamide and bisacrylamide were from Promega (Madison, WI, U.S.A.). The Mono P (HR 5/5) column for fast

Received April 15, 1994; revised manuscript received August 17. 1994; accepted August 31, 1994.

Address correspondence and reprint requests to Dr. G.-D. Chang at Graduate Institute of Biochemical Sciences, National Taiwan University, P.O. Box 23-106, Taipei 10098, Taiwan.

Abbreviations used: FPLC, fast protein liquid chromatography; PBS, phosphate-buffered saline; PMF, perimeningeal fluid; SDS, sodium dodecyl sulfate. 
protein liquid chromatography (FPLC), Sepharose CL-6B, Sephacryl S-200 HR, and low-molecular-weight protein markers were from Pharmacia (Uppsala, Sweden). Prestained protein markers were from Stratagene ( La Jolla, CA, U.S.A.). All other analytical chemicals were from either E. Merck or Sigma.

\section{Collection of body fluid}

PMF was collected by suction after removing the skull of bighead carp (Aristichthys nobilis) and separated from lipid by centrifugation at $2,000 \mathrm{~g}$ for $30 \mathrm{~min}$. Blood was collected by inserting a 22 -gauge needle in the caudal vein. Blood was allowed to clot at room temperature for $1 \mathrm{~h}$ and at $4^{\circ} \mathrm{C}$ for $16 \mathrm{~h}$ before centrifugation to collect serum. Ovarian fluid and milt were collected from common carp (Cyprinus carpio). Fish were first injected with pituitary homogenate in phosphate-buffered saline (PBS) (two pituitary equivalents per fish). Ovulation and spermiation were induced $12 \mathrm{~h}$ after injection, and the fluids accompanying ovulation (ovarian fluid) and spermiation (milt) were collected by centrifugation at $1,000 \mathrm{~g}$ for $20 \mathrm{~min}$.

\section{Purification of p62}

Solid ammonium sulfate was added to $65 \%$ saturation to $100 \mathrm{ml}$ of PMF (2.1 g of protein) with constant stirring on ice. The supernatant was collected by centrifugation at $12,000 \mathrm{~g}$ for $30 \mathrm{~min}$, and the ammonium sulfate concentration was brought to $80 \%$ saturation. The suspension was centrifuged at $12,000 \mathrm{~g}$ for $30 \mathrm{~min}$, and the pellet was then dissolved in $40 \mathrm{ml}$ of $100 \mathrm{~m} M$ ammonium bicarbonate. Half of the sample was applied to a Sepharose CL-6B column ( 3 $\times 70 \mathrm{~cm}$ ) equilibrated with $100 \mathrm{mM}$ ammonium bicarbonate and separated at a flow rate of $30 \mathrm{ml} / \mathrm{h}$. The fractions (CL$6 \mathrm{~B}$ ) containing trypsin inhibitory activity were pooled, lyophilized, dissolved in $20 \mathrm{ml}$ of $100 \mathrm{mM}$ ammonium bicarbonate, and applied to a Sephacryl S-200 column $(3 \times 80$ $\mathrm{cm}$ ) equilibrated with 100$) \mathrm{m} M$ ammonium bicarbonate and separated at a flow rate of $30 \mathrm{ml} / \mathrm{h}$. Two peaks $(\mathrm{S} 200-\mathrm{a}$ and $-b$ ) containing trypsin inhibitory activity were pooled separately, lyophilized, and dissolved in $4 \mathrm{ml}$ of $1.5 \mathrm{Mam}$ monium sulfate in $20 \mathrm{mM}$ sodium phosphate buffer $(\mathrm{pH}$ $7.0) / 1 \mathrm{~m} M$ EDTA (solution A). For cach injection, $0.5 \mathrm{ml}$ of the sample was applied to a HPLC TSK-phenyl column (E. Merck). Operation of the HPLC TSK-phenyl column used two solutions: solution A and solution B $(50 \%$ ethylene glycol in $10 \mathrm{mM}$ sodium phosphate, $\mathrm{pH} 7.0$ ). Elution was performed with solution $A$ for $10 \mathrm{~min}$ followed by a $30-\mathrm{min}$ linear gradient from solution $A$ to solution $B$ and 10 min of $100 \%$ solution B at a constant flow rate of $0.8 \mathrm{ml} / \mathrm{min}$ (FPLC system; Pharmacia LKB, Uppsala, Sweden ). The active fractions (phenyl-a from $\mathrm{S} 200$-a and phenyl-b from $\mathrm{S} 200-\mathrm{b}$ ) were pooled, dialyzed against $50 \mathrm{~m} M$ ammonium bicarbonate, lyophilized, and subjected to chromatography on a FPLC Mono P HR5/5 column. Either $0.5 \mathrm{mg}$ of phenyl-a or 1 $\mathrm{mg}$ of phenyl-b was used for each injection, respectively. Purification was achieved by a 10 -min elution with solution C (25 m $M$ MES, pH 7.1), a 30-min linear gradient from solution C to solution D ( $10 \%$ Polybuffer $74, \mathrm{pH} 4.0$ ), and a 10 -min elution with solution $D$ at a constant flow rate of $0.8 \mathrm{ml} / \mathrm{min}$. The active fractions (Mono-P-a from phenyl-a and Mono-P-b from phenyl-b) were pooled, dialyzed against $100 \mathrm{~m} M$ ammonium bicarbonate, and lyophilized. Protein concentrations were determined by a Coomassie Brilliant Blue binding assay with bovine serum albumin as the standard (Bradford, 1976). Gel electrophoresis was performed using a Tricine sodium dodecyl sulfate (SDS) - polyacrylamide gel system as described previously ( Schägger and von Jagow, 1987). The gel concentration was $7.5 \%$, and the bisacrylamide to acrylamide ratio was $6 \%$.

\section{Immunization and western blot analysis}

The Mono-P-b fraction was dissolved in PBS and thoroughly mixed with an equal volume of Freund's complete adjuvant for the first injection or Freund's incomplete adjuvant for the second and third injections. Approximately 100 $\mu \mathrm{g}$ of p62 was injected subcutaneously into the back of a guinea pig during each immunization, biweekly. Ten days after the third injection, the blood was collected by heart puncture, and serum was stored at $4{ }^{\circ} \mathrm{C}$. Western blotting was carried out using guinea pig anti-p62 antiserum ( $1: 2,000$ dilution ) and horseradish peroxidase-conjugated second antibody $(1: 1,000$ dilution $)$ after clectrotransfer to nitrocellulose paper (pore size, $0.22 \mu \mathrm{m}$; Sartorius). Immunoreactive bands were detected by the $\mathrm{NiCl}_{2}$ enhancement method (Harlow and Lane, 1988).

\section{Chromogenic assay with peptide-p-nitroanilide substrates}

The proteolytic activitics of trypsin, chymotrypsin, and elastase was determined by using the synthetic peptides $N$ tosyl-Gly-Pro-Arg- $p$-nitroanilide, $N$-succinyl-Ala-Ala-ProPhe-p-nitroanilide, and $N$-succinyl-Ala-Ala-Pro-Leu- $p$-nitroanilide, respectively (Lottenberg et al., 1981). Protease $(0.5 \mu \mathrm{g})$ was incubated with various amounts of p62 in 20 $\mu 1$ of PBS for $1 \mathrm{~min}$ at $4^{\circ} \mathrm{C}$. The volume was then brought to $970 \mu \mathrm{l}$; residual enzyme activity was assayed by addition of $30 \mu .1$ of the peptide-p-nitroanilide substrate $(1 \mathrm{mg} / \mathrm{ml})$, and hydrolysis of the substrate was monitored continuously at $405 \mathrm{~nm}$. Under these conditions, reaction rates were linear for $15 \mathrm{~s}$. Column fractions from each purification step were monitored for trypsin inhibitory activity. One unit of inhibitory activity was defined as the amount of protein that inhibited $0.5 \mu \mathrm{g}$ of trypsin by $85 \%$ because at a $1: 1$ molar ratio, the purified Mono-P-b fraction inhibited trypsin activity by $85 \%$.

\section{Deglycosylation of p62}

Five micrograms of Mono-P-a or Mono-P-b fraction was dissolved in $25 \mu \mathrm{l}$ of $0.1 \%$ SDS and $1 \%$ Triton $\mathrm{X}-100$ in $50 \mathrm{~m} M$ sodium phosphate buffer $(\mathrm{pH} 7.0)$, and $50 \mu \mathrm{U}$ of endoglycosidase $F$ or $0.5 \mathrm{mU}$ of $O$-glycosidase was added. The reaction was carried out at $37^{\circ} \mathrm{C}$ for $16 \mathrm{~h}$ and stopped by addition of an equal volume of twice-concentrated SDS sample buffer. The reaction products were then analyzed by SDS-gel electrophoresis and Coomassie Brilliant Blue staining.

\section{Formation of serpin-enzyme complexes}

Threc micrograms of purified 062 and $1 \mu \mathrm{g}$ of protease in $5 \mu \mathrm{l}$ of PBS wcre mixed and incubated at $4^{\circ} \mathrm{C}$ for $1 \mathrm{~min}$. The reaction was stopped by addition of $20 \mu \mathrm{l}$ of the SDS sample buffer and boiling for $3 \mathrm{~min}$. The reaction products were then analyzed by SDS-gel electrophoresis. Relative aclivities of commercial trypsin and chymotrypsin were determined by densitometric analysis of the amount of serpinenzyme complex formed in the presence of excess of MonoP-b fraction (10:1, by weight). It 'vas found that $>90 \%$ of the proteases were able to form serpin-enzyme complexes. 

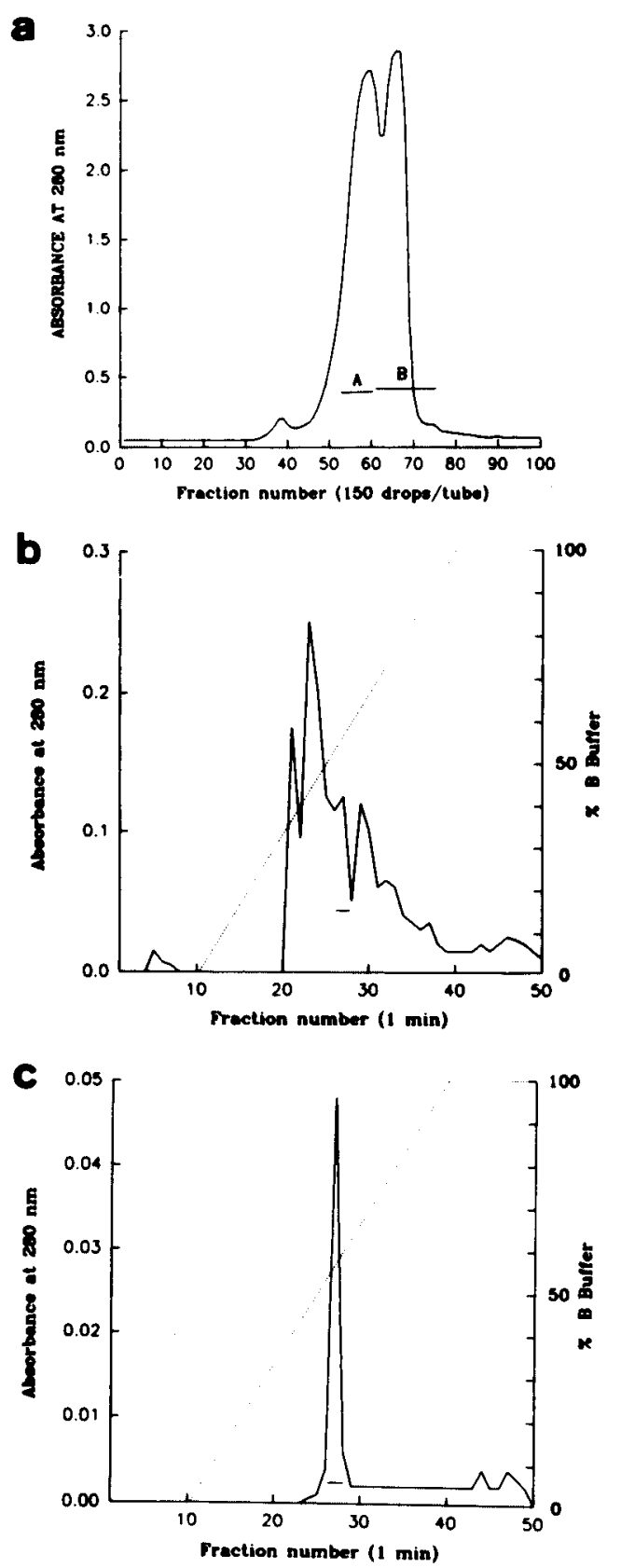

FIG. 1. Purification of p62 from carp PMF. a: Sephacryl S-200 column chromatography. b: HPLC phenyl column chromatography of S200-b. c: FPLC Mono P column chromatography of phenyl-b. Fractions containing trypsin inhibitory activity are indicated by short lines in the figures and were pooled for subsequent purification.

\section{RESULTS}

\section{Purification of p62}

Precipitated protein from a $65-80 \%$ saturated solution of ammonium sulfate was dissolved in $100 \mathrm{~m} \mathrm{M}$ ammonium bicarbonate and applied to a Sepharose CL-6B column. One major and one minor protein peak

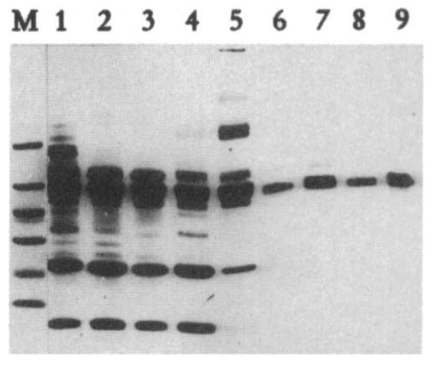

FIG. 2. SDS-polyacrylamide gel electrophoresis of purified p62. Samples from various purification steps were analyzed by electrophoresis as described in Materials and Methods. $M$, markers of $94,67,43,30,20$, and $14.4 \mathrm{kDa}$; lane $1,20 \mu \mathrm{g}$ of PMF; lane $2,15 \mu \mathrm{g}$ of ammonium sulfate fraction; lane $3,12 \mu \mathrm{g}$ of CL-6B fraction; lane 4, $10 \mu \mathrm{g}$ of $\mathrm{S} 200-\mathrm{a}$; lane $5,6 \mu \mathrm{g}$ of $\mathrm{S} 200-\mathrm{b}$; lane $6,2 \mu \mathrm{g}$ of phenyl-a; lane $7,3 \mu \mathrm{g}$ of phenyl-b; lane $8,2 \mu \mathrm{g}$ of Mono-P-a; lane $9,3 \mu \mathrm{g}$ of Mono-P-b.

were obtained (data not shown). The major protein peak was concentrated and applied to a Sephacryl S200 column. Two peaks containing trypsin inhibitory activity were resolved (Fig. la). Each peak (S200-a and -b) was separately pooled, lyophilized, and dissolved in $1.5 \mathrm{M}$ ammonium sulfate in $20 \mathrm{~m} M$ sodium phosphate buffer/1 m $M$ EDTA ( $\mathrm{pH} 7.0$ ) (buffer A) to achieve protein concentrations of $5-10 \mathrm{mg} / \mathrm{ml}$. Sample $(0.5 \mathrm{ml}$ for each assay) were then injected into a TSK-phenyl HPLC column equilibrated with buffer $A$ and eluted with a linear gradient of buffer B, consisting of $50 \%$ ethylene glycol in $20 \mathrm{~m} \mathrm{M}$ sodium phosphate buffer, $\mathrm{pH} 7.0$ (Fig. 1b). The peak containing trypsin inhibitory activity (the fourth peak) obtained from the phenyl column (phenyl-a or -b) was applied to a Mono P column (Fig. Ic) equilibrated with 25 $\mathrm{m} M$ MES ( $\mathrm{pH} 7.1$ ) and eluted with $10 \%$ Polybuffer $74(\mathrm{pH} 4.0)$. One major peak containing a 62-kDa protein ( $p 62$ ) was obtained from Mono P chromatography (Mono-P-a from phenyl-a and Mono-P-b from phenyl-b; Fig. 2). For the sake of brevity, only chro-

TABLE 1. Purification of $\alpha_{r}$-antitrypsin (p62) from bighead carp $P M F$

\begin{tabular}{lrrrr}
\hline \multicolumn{1}{c}{ Step } & $\begin{array}{c}\text { Total } \\
\text { protein } \\
(\mathrm{mg})\end{array}$ & $\begin{array}{c}\text { Total } \\
\text { activity } \\
(\mathrm{U})\end{array}$ & $\begin{array}{c}\text { Specific } \\
\text { activity } \\
\text { (U/mg) }\end{array}$ & $\begin{array}{c}\text { Recovery } \\
(\%)\end{array}$ \\
\hline CSF & 2,105 & 20,000 & 9.5 & 100 \\
AS & 631 & 10.400 & 16.48 & 52 \\
CL-6B & 327 & 6.600 & 20.18 & 33 \\
S200-a & 92 & 840 & 9.2 & 4.2 \\
S200-b & 157 & 3,200 & 20.38 & 16 \\
Phenyl-a & 4.1 & 870 & 212.19 & 4.4 \\
Phenyl-b & 8.5 & 2.500 & 294.12 & 12.5 \\
Mono-P-a & 1.5 & 833 & 555.33 & 4.2 \\
Mono-P-b & 4.5 & 2.830 & 628.89 & 14.1 \\
\hline
\end{tabular}

One unit of trypsin inhibitory activity was defined as the amount of protein that inhibited the activity of $0.5 \mu \mathrm{g}$ of trypsin by $85 \%$. 

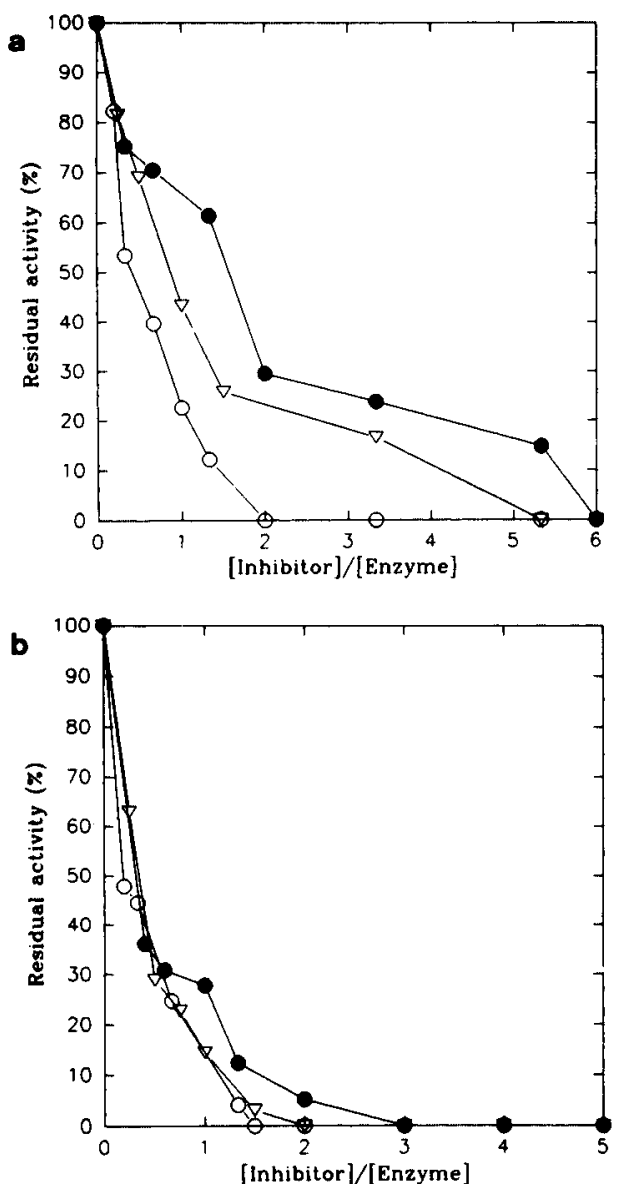

FIG. 3. Inhibitor activity of $p 62$ against bovine trypsin, chymotrypsin, and porcine elastase. Various amounts of Mono-P-a (a) and Mono-P-b (b) were incubated with $0.5 \mu \mathrm{g}$ of trypsin $(-\bigcirc-)$, chymotrypsin $(-\nabla-)$, or elastase $(--)$ ) and assayed as described in Materials and Methods.

matograms for the purification of Mono-P-b are shown. The results of purification are summarized in Table 1.

\section{Protease inhibitor activity}

Inhibitor capacity (molar inhibitory activity) of Mono-P-a and Mono-P-b against trypsin, chymotrypsin, and elastase is shown in Fig. 3. Inhibition of tryp$\sin$, chymotrypsin, and elastase by Mono-P-b occurred at a 1:1 molar ratio (observations by extrapolating the curve ). Complete inhibition of the proteases, however, was observed at a molar ratio of 1.5:1, 2:1, and 3:1, respectively (Fig. 3b). In contrast, Mono-P-a inhibited trypsin, chymotrypsin, and elastase at a molar ratio of $1.3: 1,2: 1$, and $3: 1$, respectively. Complete inhibition occurred at $2: 1,5: 1$, and $6: 1$ molar ratios, respectively (Fig. 3a). Incubation of Mono-P-a and Mono-P-b with chymotrypsin, elastase, or trypsin resulted in formation of SDS-stable complexes with apparent molecular masses of 75-78 kDa (Fig. 4). The complex formation ability by the two forms of protease inhibitor with any of the proteases did not differ significantly.

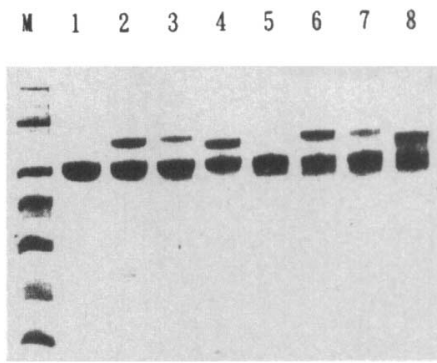

FIG. 4. Complex formation between $p 62$ and serine proteases. Mono-P-a or Mono-P-b $(3 \mu \mathrm{g})$ was incubated with $1 \mu \mathrm{g}$ of protease on ice for $1 \mathrm{~min}$. The reaction was then terminated by addition of SDS sample buffer and analyzed by SDS-gel electrophoresis. $M$, markers of $94,67,43,30,20$, and $14.4 \mathrm{kDa}$; lane 1 , Mono-P-b; lane 2, Mono-P-b/chymotrypsin; lane 3, Mono-P-b/ elastase; lane 4, Mono-P-b/trypsin; lane 5, Mono-P-a; lane 6, Mono-P-a/chymotrypsin; lane 7, Mono-P-a/elastase; lane 8 , Mono-P-a/trypsin

\section{Tissue distribution}

Both Mono-P-a and Mono-P-b fractions were recognized by the antiserum raised against Mono-P-b (data not shown). The presence of $\mathrm{p} 62$ in different body fluids and tissue extracts was examined by western blotting with polyclonal antiserum against p62 (Fig. 5 ). All samples contained an immunoreactive protein of similar molecular mass except for head kidney. p62 was found to be abundant in serum and PMF as well as the brain, kidney, and pituitary. Immunoreactive proteins of different molecular sizes were detected in serum, PMF, head kidney, kidney, and liver. On the other hand, p62 was not detected in membrane preparations from any tissue (data not shown).

\section{Deglycosylation of $\mathrm{p} 62$ by endoglycosidases}

The molecular mass of both Mono-P-a and MonoP-b decreased from 62 to $53 \mathrm{kDa}$ after carbohydrate was removed with endoglycosidase F (Fig. 6). On shorter treatment with this enzyme, a product of inter-
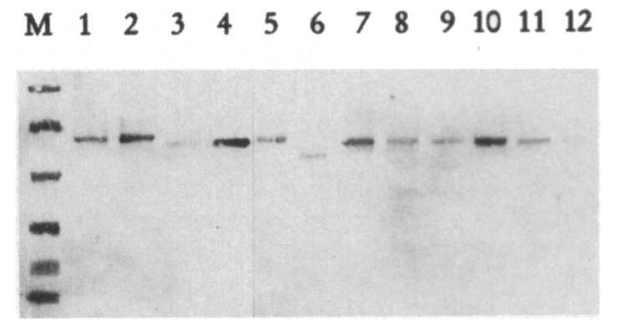

FIG. 5. Distribution of p62 in body fluids and tissue extracts. Proteins from various body fluids and tissue extracts were electrophoresed on an SDS-polyacrylamide gel and subjected to western blotting with an antiserum against purified p62 (Mono$\mathrm{P}-\mathrm{b})$. M, prestained markers of $94,75,45,30,22$, and $18 \mathrm{kDa}$; lane $1,0.02 \mu \mathrm{l}$ of serum; lane $2,0.02 \mu \mathrm{l}$ of PMF; lane $3,0.2 \mu \mathrm{l}$ of ovarian fluid; lane 4, $0.2 \mu \mathrm{l}$ of milt; lanes $5-12,10 \mu \mathrm{g}$ of tissue extract from brain, head kidney, kidney, liver, muscle, pituitary, spleen, and ovary. 


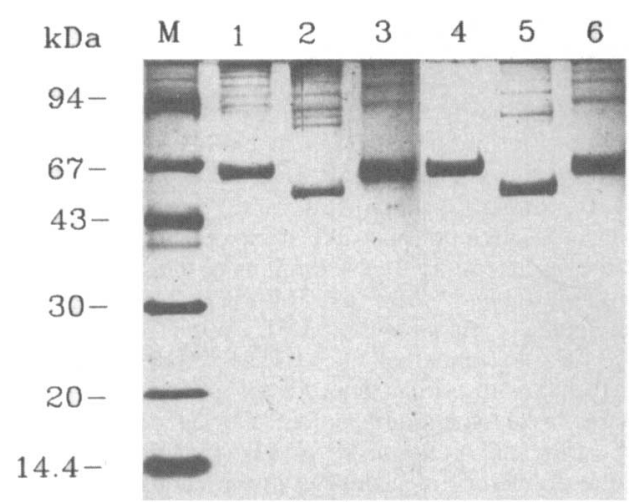

FIG. 6. Deglycosylation of p62 by endoglycosidase F. Five micrograms of Mono-P-a (lanes 1-3) or Mono-P-b (lanes 4-6) was dissolved in $25 \mu$ of $50 \mathrm{mM}$ sodium phosphate buffer containing $0.1 \%$ SDS and $1 \%$ Triton $X-100, \mathrm{pH} 7.0$. Endoglycosidase $F(50$ $\mu \mathrm{U}$; lanes 2 and 5 ) or $0.5 \mathrm{mU}$ of $\mathrm{O}$-glycosidase (lanes 3 and 6) was added for $16 \mathrm{~h}$ at $37^{\circ} \mathrm{C}$. Mock-treated p62 (lanes 1 and 4) is included for comparison.

mediate size ( $57 \mathrm{kDa}$ ) was observed (data not shown). It appears that the protein has two N-linked carbohydrate moieties. However, the apparent molecular mass of 062 was not affected by $O$-glycosidase treatment.

\section{DISCUSSION}

In this study, two protease inhibitors have been purified from the bighead carp PMF (Mono-P-a and -b). Both proteins inhibited trypsin, chymotrypsin, and elastase. Mono-P-b was equally potent in inhibiting the three enzymes, whereas Mono-P-a was more active against trypsin. They possess several similar chemical properties, such as molecular mass in native and deglycosylated forms, inhibitory activity toward trypsin, chymotrypsin, and elastase, similar hydrophobicity (elution time from the phenyl column), similar isoelectric point (elution time from the Mono P column), and cross-immunoreactivity.

Both proteins may be members of the serpin family (serine protease inhibitors) on the basis of the two characteristics: First, both are glycoproteins whose carbohydrate moieties can be removed by endoglycosidase F. Second, both inhibitors form SDS-resistant complexes with trypsin, chymotrypsin, and elastase, similar to $\alpha_{1}$-antitrypsin (Travis and Salvesen, 1983). The fact that the antiserum raised against Mono-P-b can recognize Mono-P-a suggests that the two inhibitors are isoforms of the same molecule. Comparison of the deduced amino acid sequence of p62 in our accompanying article (Huang et al., 1995) with other serpin members has revealed that p62 is closely related to $\alpha_{1}$-antitrypsin. Polymorphism of $\alpha_{1}$-antitrypsin may arise from carbohydrate microheterogeneity and from structural differences of the polypeptide (Travis and Salvesen, 1983). The fact that the two isoforms were resolved by molecular sieving suggests that one of the isoforms (Mono-P-a) may associate with other proteins in PMF and thus behave as a molecule of larger mass.

The average concentration of this protease inhibitor in $\mathrm{PMF}$ is $\sim 0.3 \mathrm{mg} / \mathrm{ml}$, higher than that in serum $(0.21 \mathrm{mg} / \mathrm{ml})$ (G.-D. Chang et al., unpublished data). Proteases and protease inhibitors have been shown to play a diversity of roles in the CNS. Proteases (trypsin, plasmin, $\alpha_{1}$-chymotrypsin, thrombin, or elastase) increase the levels of biosynthesis and secretion of nerve growth factor by cultured astroglial cells ( Neveu et al., 1993 ). In addition, thrombin reverses the differentiation status of astroglial cells treated with agents that elevate intracellular cyclic AMP levels (Cavanaugh et al., 1990) and adenovirus-transformed retinoblast cells (Grand et al., 1989). Thrombin also stimulates the mitosis of these cells. The effects of thrombin can be blocked and reversed by protease nexin-1, a thrombinspecific inhibitor (Cavanaugh et al., 1990). Protease present in the CNS may be of blood origin (mostly serine proteases) or of brain origin. In fact, proteases such as plasminogen activator (Kalderon, 1984; Krystosek and Seeds, 1984; Pittman, 1985), elastase ( Nakajima et al., 1992), chymotrypsin-like protease ( Nelson and Siman, 1990; Nelson et al., 1993), and metalloproteases (Pittman, 1985; Nelson and Siman, 1989) have been identified in the CNS. Because $\alpha_{1}$-antitrypsin possesses inhibitory activity toward most serine proteases, the presence of this inhibitor in PMF may provide regulatory control of the serine proteases found in the CNS. $\alpha_{1}$-Antichymotrypsin has been identified in the brain amyloid deposits of Alzheimer's disease, and levels of $\alpha_{1}$-antichymotrypsin mRNA and soluble proteins are elevated in the brain in Alzheimer's patients (Abraham et al., 1988). A $\beta$ peptide, a peptide fragment of the $\beta$-amyloid precursor protein, assembles in vitro into $70-90$ - $\AA$-diameter fibrils resembling native amyloid, and $\alpha_{1}$-antichymotrypsin can bind to the $A \beta$ fibrils and alter the morphology (Fraser et al., 1993). Therefore, proteases and their inhibitors appear to play some important roles in the CNS.

Acknowledgment: We thank Drs. L. S. Kao and S. R. Roffler for critically reading the manuscript. This study was supported by grants from the National Science Council and from Academia Sinica, Taiwan, R.O.C.

\section{REFERENCES}

Abraham C. R., Selkoe D. J., and Potter H. (1988) Immunochemical identification of the serine protease inhibitor $\alpha_{1}$-antichymotryp$\sin$ in the brain amyloid deposits of Alyheimer's disease. Cell $\mathbf{5 2}, 487-501$.

Bradford M. M. ( 1976) A rapid and sensitive method for the quantitation of microgram quantities of protein utilizing the principle of protein-dye binding. Anal. Biochem. 72, 248-254.

Cavanaugh K. P., Gurwitz D., Cunningham D. D., and Bradshaw R. A. (1990) Reciprocal modulation of astrocyte stellation by thrombin and protease nexin-1. J. Neurochem. 54, 1735-1743.

Fraser P. E., Nguyen J. T., McLachlan D. R., Abraham C. R., and 
Kirschner D. A. ( 1993) $\alpha_{1}$-Antichymotrypsin binding to $\mathrm{Alz}-$ heimer $\mathrm{A} \beta$ peptides is sequence specific and induces fibril disaggregation in vitro. $J$. Neurochem. 61, 298-305.

Grand R. J. A., Grabham P. W., Gallimore M. J., and Gallimore P. H. (1989) Modulation of morphological differentiation of human neuroepithelial cells by serine proteases: independence from blood coagulation. EMBO J. 8, 2209-2215.

Harlow E. and Lane D. ( 1988 ) Immunoblotting, in Antibodies (Harlow E. and Lane D., eds), pp. 471-510. Cold Spring Harbor Laboratory, Cold Spring Harbor, New York.

Hoffmann W. (1992) Goldfish ependymins: cerebrospinal fluid proteins of meningeal origin. Prog. Brain Res. 91, 13-17.

Huang C.-J., Lee M.-S., Huang F.-L., and Chang G.-D. (1995) A protease inhibitor of the serpin family is a major protein in carp perimeningeal fluid: II. cDNA cloning, sequence analysis, and Escherichia coli expression. J. Neurochem. 64, 1721-1727.

Jones H. C. (1979) Comparative aspects of the cerebrospinal fluid system in vertebrates. Sci. Prog. 66, 171-190.

Kalderon N. (1984) Schwann cell proliferation and localized proteolysis: expression of plasminogen-activator activity predomi nates in the proliferating cell populations. Proc. Natl. Acad. Sci. USA 81, 7216-7220

Krystosek A. and Seeds N. W. (1984) Peripheral neurons and Schwann cells secrete plasminogen activator. J. Cell Biol. 98, $773-776$.

Lottenberg R., Christensen U., Jackson C. M., and Coleman P. L. (1981) Assay of coagulation proteases using peptide chromogenic and fluorogenic substrates. Methods Enzymol. 80, $341-$ 361

Müller-Schmid A., Rinder H., Lottspeich F., Gertzen E.-M., and Hoffmann W. (1992) Ependymins from the cerebrospinal fluid of salmonid fish: gene structure and molecular characterization. Gene 118, 189-196.

Nakajima K., Shimojo M., Hamanoue M., Ishiura S., Sugita H., and Kohsaka S. (1992) Identification of elastase as a secretory protease from cultured rat microglia. J. Neurochem. 58, 1401 1408
Nelson R. B. and Siman R. ( 1989) Identification and characterization of calcium-dependent metalloproteases in rat brain. J. Neurochem. 53, 641-647.

Nelson R. B. and Siman R. (1990) Clipsin, a chymotrypsin-like protease in rat brain which is irreversibly inhibited by $\alpha_{1}$-antichymotrypsin. J. Biol. Chem. 265, 3836-3843.

Nelson R. B., Siman R., Iqbal M. A., and Potter H. ( 1993) Identifi cation of a chymotrypsin-like mast cell protease in rat brain capable of generating the $\mathrm{N}$-terminus of the Alzheimer amyloid $\beta$-protein. J. Neurochem. 61, 567-577.

Neveu I., Jehan F., Jandrot-Perrus M., Wion D., and Brachet P. (1993) Enhancement of the synthesis and secretion of nerve growth factor in primary cultures of glial cells by proteases: a possible involvement of thrombin. $J$. Neurochem. 60, 858-867.

Nilsson C., Lindvall-Axelsson M., and Owman C. (1992) Neuroendocrine regulatory mechanisms in the choroid plexus-cerebrospinal fluid system. Brain Res. Rev. 17, 109-138.

Pittman R. N. (1985) Release of plasminogen activator and a calcium dependent metalloprotease from cultured sympathetic and sensory neurons. Dev. Biol. 110,91-101.

Schägger H. and von Jagow G. ( 1987) Tricine-sodium dodecyl sulfate-polyacrylamide gel electrophoresis for the separation of proteins in the range from 1 to $100 \mathrm{kDa}$. Anal. Biochem. 166 , 368-379.

Shashoua V. E. (1985) The role of brain extracellular proteins in neuroplasticity and learning. Cell. Mol. Neurobiol. 5, 183-207.

Spector R. and Johanson C. E. (1989) The mammalian choroid plexus. Sci. Am. 261 (5), 48-54.

Travis J. and Salvesen G. S. ( 1983 ) Human plasma proteinase inhibitors. Annu. Rev. Biochem. 52, 655-709.

Walsh M. J., Limos L., and Tourtellotte W. W. (1984) Two-dimensional electrophoresis of cerebrospinal fluid and ventricular fluid proteins, identification of enriched and unique proteins, and comparison with serum. $J$. Neurochem. 43, 1277-1285.

Wiederkehr F., Ogilvie A., and Vonderschmitt D. J. ( 1987) Cerebrospinal fluid proteins studied by two-dimensional gel electrophoresis and immunoblotting technique. J. Neurochem. 49, 363372. 